medRxiv preprint doi: https://doi.org/10.1101/2021.06.09.21257915; this version posted June 12, 2021. The copyright holder for this preprint (which was not certified by peer review) is the author/funder, who has granted medRxiv a license to display the preprint in perpetuity. It is made available under a CC-BY-NC-ND 4.0 International license .

\title{
REGEN-COV Antibody Cocktail in Outpatients with Covid-19
}

David M. Weinreich, M.D. ${ }^{\top 1}$, Sumathi Sivapalasingam, M.D. ${ }^{1}$, Thomas Norton, M.D. ${ }^{1}$, Shazia Ali,

Pharm.D. ${ }^{1}$, Haitao Gao, Ph.D. ${ }^{1}$, Rafia Bhore, Ph.D. ${ }^{1}$, Andrea T. Hooper, Ph.D. ${ }^{1}$, Jennifer D.

Hamilton, Ph.D. ${ }^{1}$, Bret J. Musser, Ph.D. ${ }^{1}$, Yuhwen Soo, Ph.D. ${ }^{1}$, Diana Rofail, Ph.D. ${ }^{1}$, Joseph Im, B.S. ${ }^{1}$, Christina Perry, M.B.A. ${ }^{1}$, Cynthia Pan, B.Pharm. ${ }^{1}$, Romana Hosain, M.D., M.P.H. ${ }^{1}$, Adnan Mahmood, M.D. ${ }^{1}$, John D. Davis, Ph.D. ${ }^{1}$, Kenneth C. Turner, Ph.D. ${ }^{1}$, Alina Baum, Ph.D. ${ }^{1}$, Christos A. Kyratsous, Ph.D. ${ }^{1}$, Yunji Kim, Pharm.D. ${ }^{1}$, Amanda Cook, B.S., Dip.Reg.Aff. ${ }^{1}$, Wendy Kampman, M.D. ${ }^{1}$, Ximena Graber, M.D., CPI, CCRP. ${ }^{2}$, Gerard Acloque, M.D. ${ }^{3}$, Yessica Sachdeva, M.D. ${ }^{4}$, Joseph A. Bocchini, M.D. ${ }^{5}$, Anita Kohli, M.D. ${ }^{6}$, Bari Kowal, M.S. ${ }^{1}$, Thomas DiCioccio, Ph.D. ${ }^{1}$, Neil Stahl, Ph.D. ${ }^{1}$, Leah Lipsich, Ph.D. ${ }^{1}$, Ned Braunstein, M.D. ${ }^{1}$, Gary Herman, M.D. ${ }^{1}$, and George D. Yancopoulos, M.D., Ph.D. ${ }^{1}$, for the Trial Investigators

${ }^{1}$ Regeneron Pharmaceuticals, Inc., Tarrytown, NY; ${ }^{2}$ AGA Clinical Trials, Hialeah, FL; ${ }^{3}$ Universal Medical and Research Center, LLC, Miami, FL; ${ }^{4}$ Arizona Liver Health, Chandler, AZ; ${ }^{5}$ Willis-Knighton Physician Network, Shreveport, LA; ${ }^{6}$ Arizona Liver Health, Tucson, AZ.

The authors' affiliations are as follows: Regeneron Pharmaceuticals (D.M.W., S.S., T.N., S.A., H.G., R.B., A.H., J.H., B.M., Y. Soo, D.R., J.I., C. Perry, C. Pan, R.H., A.M., J.D.D., K.C.T., A.B., C.K., Y.K., A.C., W.K., B.K., T.D., N.S., L.L., N.B., G.H., G.D.Y.), Tarrytown, NY; AGA Clinical Trials (X.G.), Hialeah, FL; Universal Medical and Research Center, LLC (G.A.), Miami, FL; Arizona Liver Health (Y. Sachdeva), Chandler, AZ; Willis-Knighton Physician Network (J.A.B), Shreveport, LA; and Arizona Liver Health (A.K.), Tucson, AZ. 
medRxiv preprint doi: https://doi.org/10.1101/2021.06.09.21257915; this version posted June 12, 2021. The copyright holder for this preprint (which was not certified by peer review) is the author/funder, who has granted medRxiv a license to display the preprint in perpetuity.

\section{ABSTRACT}

Word count: 240

Background: REGEN-COV (casirivimab and imdevimab) antibody cocktail reduced SARS-CoV-2 viral load in descriptive analyses of the first 275 Covid-19 outpatients in the phase $1 / 2$ portion of an ongoing double-blind, seamless phase 1/2/3 trial.

Methods: This final analysis of the phase $1 / 2$ portion includes 799 patients: 275 (group1) and 524 (group-2). Patients were randomized (1:1:1) to placebo, 2400mg REGENCOV, or $8000 \mathrm{mg}$ REGEN-COV, and characterized at baseline for endogenous immune response against SARS-CoV-2 (serum antibody-positive/negative). Efficacy was assessed in patients with a positive baseline RT-qPCR result; safety was assessed in all treated patients. Prespecified hierarchical analyses of virologic endpoints in group-2 were performed to confirm previously reported descriptive analyses from group-1. The proportion of patients with $\geq 1$ Covid-19-related medically-attended visit (MAV) through day 29 was assessed in group-1+2.

Results: Time-weighted average reduction in viral load $\left(\log _{10}\right.$ copies $\left./ \mathrm{ml}\right)$ through day 7 was significantly greater with REGEN-COV (combined $2400 \mathrm{mg}+8000 \mathrm{mg}$ dose groups) versus placebo in patients with baseline viral load $>10^{7}$ copies $/ \mathrm{ml}$ (prespecified primary endpoint): $-0.68(95 \% \mathrm{Cl},-0.94$ to $-0.41 ; \mathrm{P}<0.0001)$. This reduction was -0.73 $(P<0.0001)$ in serum antibody-negative patients and $-0.36(P=0.0003)$ in the overall population. Proportions of patients with $\geq 1$ Covid-19-related MAV were 2.8\% (12/434) with REGEN-COV versus $6.5 \%$ (15/231) with placebo ( $P=0.024$; relative risk reduction $=57 \%$ ), with greater relative risk reductions in MAVs in patients with $\geq 1$ risk factor for hospitalization (71\%). Adverse events were similar across groups.

Conclusions: REGEN-COV treatment of outpatients significantly reduced SARS-CoV-2 viral load and Covid-19-related medically-attended visits. 
medRxiv preprint doi: https://doi.org/10.1101/2021.06.09.21257915; this version posted June 12, 2021. The copyright holder for this preprint (which was not certified by peer review) is the author/funder, who has granted medRxiv a license to display the preprint in perpetuity. It is made available under a CC-BY-NC-ND 4.0 International license.

(Funded by Regeneron Pharmaceuticals and the Biomedical and Advanced Research and Development Authority of the Department of Health and Human Services; ClinicalTrials.gov number, NCT04425629.) 
medRxiv preprint doi: https://doi.org/10.1101/2021.06.09.21257915; this version posted June 12, 2021. The copyright holder for this preprint (which was not certified by peer review) is the author/funder, who has granted medRxiv a license to display the preprint in perpetuity.

It is made available under a CC-BY-NC-ND 4.0 International license .

\section{INTRODUCTION}

COVID-19 is caused by the severe acute respiratory syndrome coronavirus 2 (SARSCoV-2), which first emerged in China in December 2019. ${ }^{1,2}$ Covid-19 severity varies widely among patients, ranging from mild symptoms to severe disease requiring hospitalization or leading to death. ${ }^{3-7}$ SARS-CoV-2 viral load has been associated with disease severity and mortality. ${ }^{8,9}$ Treatments that reduce viral burden may improve Covid-19 clinical outcomes.

REGEN-COV (casirivimab and imdevimab; previously REGN-COV2) is a fully-human, neutralizing monoclonal antibody combination therapy directed against the receptor binding domain (RBD) of the SARS-CoV-2 spike (S) protein. ${ }^{10}$ Because of previous experience with the emergence of viral variants resistant to a treatment consisting of a single monoclonal antibody (ie, viral escape), ${ }^{11}$ we pursued a "cocktail" approach. The two antibodies, casirivimab (REGN10933) and imdevimab (REGN10987), bind simultaneously and non-competitively to the RBD of the S protein and have been shown to protect against viral escape in preclinical studies. ${ }^{12}$ Importantly, the REGEN-COV cocktail retains its potent in vitro neutralizing activity against emerging viral variants such as those first identified in the UK (B.1.1.7) and South Africa (B.1.351) - that are resistant to other single and combination antibody treatments. ${ }^{13}$ In vivo efficacy of REGEN-COV was previously demonstrated in two animal models (rhesus macaques and golden hamsters) as evidenced by reduced viral load in both models, reduced virus-induced lung pathology in rhesus macaques, and protection from weight loss in golden hamsters. ${ }^{14}$ In the initial descriptive interim analysis of the first 275 Covid-19 outpatients from the ongoing phase $1 / 2 / 3$ trial reported herein, we previously reported 
medRxiv preprint doi: https://doi.org/10.1101/2021.06.09.21257915; this version posted June 12, 2021. The copyright holder for this preprint (which was not certified by peer review) is the author/funder, who has granted medRxiv a license to display the preprint in perpetuity. It is made available under a CC-BY-NC-ND 4.0 International license.

that administration of the REGEN-COV antibody cocktail rapidly reduced viral load, with greater reductions in those who had not yet mounted an endogenous immune response or had a high viral load at baseline.${ }^{15}$ Here we describe the confirmatory prespecified virologic results of a subsequent phase 2 analysis in 524 additional outpatients with Covid-19, as well as the final phase $1 / 2$ analysis of clinical and safety outcomes in all 799 outpatients. 
medRxiv preprint doi: https://doi.org/10.1101/2021.06.09.21257915; this version posted June 12, 2021. The copyright holder for this preprint (which was not certified by peer review) is the author/funder, who has granted medRxiv a license to display the preprint in perpetuity.

\section{METHODS}

\section{TRIAL DESIGN}

This is an ongoing, adaptive, multicenter, randomized, double-blind, placebo-controlled, seamless phase 1/2/3 trial in Covid-19 outpatients (NCT04425629). The trial continues to recruit beyond the 799 patients for whom data are described in this report; phase 3 results will be reported at trial completion.

The phase $1 / 2$ trial design was previously described. ${ }^{15}$ Patients were randomly assigned (1:1:1) to receive placebo, $2400 \mathrm{mg}$ REGEN-COV (1200mg each of casirivimab and imdevimab; low dose), or $8000 \mathrm{mg}$ REGEN-COV (4000mg each of casirivimab and imdevimab; high dose) (Figure S1). The 29-day phase 2 trial included a screening/baseline period (days -1 to 1 ), a follow-up period (days 2 to 25 ), and an endof-study visit (day 29). The phase 1 and 2 portions of the trial were identical, except for additional pharmacokinetic analyses in phase 1.

\section{PATIENTS}

Eligible patients were $\geq 18$ years of age and nonhospitalized, with a confirmed SARSCoV-2-positive nasopharyngeal (NP) polymerase chain reaction (PCR) test result $\leq 72$ hours and symptom onset $\leq 7$ days before randomization. Randomization was stratified by country and presence or absence of $\geq 1$ risk factor for severe Covid-19: age $>50$ years, obesity (BMI >30), immunosuppression, and chronic cardiovascular, metabolic, liver, kidney, or lung disease. The full list of inclusion and exclusion criteria was previously described. ${ }^{15}$ 
medRxiv preprint doi: https://doi.org/10.1101/2021.06.09.21257915; this version posted June 12, 2021. The copyright holder for this preprint (which was not certified by peer review) is the author/funder, who has granted medRxiv a license to display the preprint in perpetuity.

All patients were assessed for the presence or absence of anti-SARS-CoV-2 antibodies: anti-spike [S1] IgA, anti-spike [S1] IgG, and anti-nucleocapsid IgG. Because these results were not available at randomization, patients underwent randomization regardless of their baseline serum antibody status and were subsequently grouped for analyses as serum antibody-negative (if all available tests were negative), serum antibody-positive (if any of the tests were positive), or unknown (missing or inconclusive results).

\section{INTERVENTION AND ASSESSMENTS}

At baseline (day 1), casirivimab and imdevimab (diluted in a 250-ml normal saline solution for co-administration) or saline placebo was administered intravenously over a period of 1 hour. See protocol for schedule of assessments (Supplementary Appendix).

\section{ENDPOINTS}

The primary virologic endpoint and two key secondary clinical endpoints were prespecified in this phase $1 / 2$ analysis and tested hierarchically as described in Table S1.The primary virologic endpoint was defined as the time-weighted average change in viral load ( $\log _{10}$ copies $/ \mathrm{ml}$ ) from baseline (day 1 ) through day 7 . The two key secondary clinical endpoints were (1) the proportion of patients through day 29 with $\geq 1$ Covid-19related medically-attended visit (MAV), defined as a hospitalization or ER, urgent care, or physician office/telemedicine visit that was confirmed by the investigator to be related 
medRxiv preprint doi: https://doi.org/10.1101/2021.06.09.21257915; this version posted June 12, 2021. The copyright holder for this preprint (which was not certified by peer review) is the author/funder, who has granted medRxiv a license to display the preprint in perpetuity. It is made available under a CC-BY-NC-ND 4.0 International license .

to Covid-19 and (2) the proportion of patients through day 29 with $\geq 1$ Covid-19-related MAV consisting of only hospitalization or emergency room (ER) or urgent care visit.

Safety endpoints for the phase $1 / 2$ portion of the trial included adverse events that occurred or worsened during the observation period (assessed in phase 1 only; grade 3 and 4), serious adverse events (SAEs), and adverse events of special interest (AESIs): grade $\geq 2$ hypersensitivity or infusion-related reactions.

\section{TRIAL OVERSIGHT}

Regeneron designed the trial and, with the trial investigators, gathered the data.

Regeneron analyzed the data. The investigators, site personnel, and Regeneron were unaware of the treatment-group assignments. An independent data and safety monitoring committee monitored unblinded data to make recommendations about trial modification and termination.

The trial was conducted in accordance with the principles of the Declaration of Helsinki, International Council for Harmonisation Good Clinical Practice guidelines, and applicable regulatory requirements. The local institutional review board or ethics committee at each study center oversaw trial conduct and documentation. All patients provided written informed consent before participating in the trial. 
medRxiv preprint doi: https://doi.org/10.1101/2021.06.09.21257915; this version posted June 12, 2021. The copyright holder for this preprint (which was not certified by peer review) is the author/funder, who has granted medRxiv a license to display the preprint in perpetuity. It is made available under a CC-BY-NC-ND 4.0 International license .

\section{STATISTICAL ANALYSIS}

The statistical analysis plan for the presented analysis was finalized prior to database lock and unblinding of the additional 524-patient phase 2 dataset. The full analysis set (FAS) included patients with Covid-19 symptoms who underwent randomization.

Patients with a positive SARS-CoV-2 NP PCR test $\leq 72$ hours from randomization (baseline) but negative by central lab qualitative PCR at baseline (limit of detection, 714 copies $/ \mathrm{ml}$ ) were excluded from analyses of virologic and clinical endpoints in a modified full analysis set (mFAS). Subgroup analyses by baseline serum antibody-status and baseline viral load were based on previous descriptive analyses from placebo-treated patients in this study ${ }^{15}$ and were prespecified. Safety was assessed in patients in the FAS who received study drug (active or placebo).

A previous descriptive analysis reported virologic and clinical efficacy data in the first 275 patients enrolled in the trial (analysis group-1). ${ }^{15}$ To confirm the virologic efficacy seen in group-1, analyses of virologic endpoints were conducted using data from patients 276 through 799 (524 patients; analysis group-2). Analyses of clinical endpoints and safety utilized data from all available patients, inclusive of the first 275 patients (patients 1 through 799; group-1+2).

The virologic efficacy endpoint was calculated as previously described (see also Supplementary Appendix). ${ }^{15}$ Key secondary clinical endpoints were analyzed using Fisher's exact test. Analyses of the primary virologic and two key clinical endpoints were conducted at a two-sided $\alpha=0.05$ utilizing a hierarchical testing strategy to control for type I error. Statistical analyses were performed with SAS software, version 9.4 or 
medRxiv preprint doi: https://doi.org/10.1101/2021.06.09.21257915; this version posted June 12, 2021. The copyright holder for this preprint (which was not certified by peer review) is the author/funder, who has granted medRxiv a license to display the preprint in perpetuity. It is made available under a CC-BY-NC-ND 4.0 International license.

higher (SAS Institute). Additional methods are described in the Supplementary Appendix. 
medRxiv preprint doi: https://doi.org/10.1101/2021.06.09.21257915; this version posted June 12, 2021. The copyright holder for this preprint (which was not certified by peer review) is the author/funder, who has granted medRxiv a license to display the preprint in perpetuity.

\section{RESULTS}

\section{BASELINE CHARACTERISTICS}

Between June 16, 2020 and September 23, 2020, 799 symptomatic patients underwent randomization in the phase $1 / 2$ portion of the trial: 266,267 , and 266 patients were assigned to receive low-dose REGEN-COV, high-dose REGEN-COV, or placebo, respectively (Figure S2). Among the 799 patients in group-1+2, 87 (10.9\%) tested negative in the central lab SARS-CoV-2 NP RT-qPCR assay at baseline and 47 (5.9\%) were without central lab baseline viral load data; consequently, the mFAS set comprised 665 patients. Similarly, among the 524 patients in group-2 (primary virologic efficacy analysis), the mFAS set comprised 437 patients.

Of the 799 randomized patients, the median age was 42.0 years, $47.1 \%$ were male, 9.3\% identified as Black or African American, and $50.4 \%$ identified as Hispanic or Latino (Table 1). Four-hundred and eighty-three $(60.5 \%)$ patients had $\geq 1$ risk factor for hospitalization due to Covid-19, including obesity (BMI >30; $37.3 \%$ ), age $>50$ years (29.3\%), cardiovascular disease $(20.5 \%)$, or chronic metabolic disease $(13.1 \%)$. Baseline characteristics were similar between the 275-patient group-1 and 524-patient group-2 (Table S2). ${ }^{15}$

At randomization, 408 (51.1\%) patients were serum antibody-negative, 304 (38.0\%) were serum antibody-positive, and $87(10.9 \%)$ were serum antibody-unknown. Median baseline viral load was $5.48 \log _{10}$ copies/ml (47 of 799 with missing baseline data); 256 $(32.0 \%)$ patients had baseline viral load $>10^{7}$ copies $/ \mathrm{ml}$. The mean time from symptom onset to randomization was 3.4 days in the overall trial population: 3.3 days in serum 
medRxiv preprint doi: https://doi.org/10.1101/2021.06.09.21257915; this version posted June 12, 2021. The copyright holder for this preprint (which was not certified by peer review) is the author/funder, who has granted medRxiv a license to display the preprint in perpetuity.

It is made available under a CC-BY-NC-ND 4.0 International license .

antibody-negative patients; 3.6 days in serum antibody-positive patients; 2.9 days in patients with viral load $>10^{7}$ copies $/ \mathrm{ml}$; and 3.8 days in patients with viral load $\leq 10^{7}$ copies/ml. Among 408 patients with $\geq 1$ risk factor for hospitalization in the mFAS, 336 $(82.4 \%)$ were serum antibody-negative or had viral load $>10^{4}$ copies $/ \mathrm{ml}$.

\section{NATURAL HISTORY}

Patients in the placebo arm who were serum antibody-negative at baseline had higher median viral loads at baseline compared to those who were serum antibody-positive (7.73 $\log _{10}$ copies/ml versus $3.88 \log _{10}$ copies $/ \mathrm{ml}$ ), and they took substantially longer to bring their viral levels to the lower limit of quantification or to undetectable (Figure S3;

Figure S4). Similarly, for clinical outcomes, placebo patients who were serum antibodynegative at baseline had substantially higher rates of Covid-19-related MAVs (9.7\%; $12 / 124)$ than placebo patients who were serum antibody-positive at baseline $(2.4 \%$; 2/83) (Figure S5). As the endogenous immune response was associated with baseline viral titers, there was the expected association of Covid-19-related MAV risk with baseline viral load as well as with presence of risk factors: MAVs occurred in $0 \%(0 / 55)$ of patients with baseline viral load $\leq 10^{4}$ copies $/ \mathrm{ml}$ versus $8.5 \%$ (15/176) with baseline viral load $>10^{4}$ copies/ml and MAVs occurred in $2.2 \%(2 / 89)$ of patients with no risk factors versus $9.2 \%(13 / 142)$ with $\geq 1$ risk factor.

\section{VIROLOGIC EFFICACY}

Prespecified comparisons for the virologic efficacy endpoint were assessed hierarchically in the 524-patient group-2 who were confirmed SARS-CoV-2-positive by 
medRxiv preprint doi: https://doi.org/10.1101/2021.06.09.21257915; this version posted June 12, 2021. The copyright holder for this preprint (which was not certified by peer review) is the author/funder, who has granted medRxiv a license to display the preprint in perpetuity. It is made available under a CC-BY-NC-ND 4.0 International license .

NP RT-qPCR at baseline (mFAS; n=437) (Table S1; Table 2). REGEN-COV treatment significantly reduced viral load through day 7 versus placebo in all prespecified virologic efficacy comparisons (Table 2; Figure 1; Figure S6). In the first comparison, among patients with baseline viral load $>10^{7}$ copies $/ \mathrm{ml}$, the least-squares mean difference between REGEN-COV treatment (combined 2400mg and 8000mg dose groups) and placebo in the time-weighted average (TWA) daily change in viral load through day 7 was $-0.68 \log _{10}$ copies $/ \mathrm{ml}(95 \% \mathrm{Cl},-0.94$ to $-0.41 ; \mathrm{P}<0.0001)$ (Table 2; Figure S6). Similarly, the least-squares mean difference in TWA daily change in viral load through day 7 with REGEN-COV treatment and placebo was $-0.73 \log _{10}$ copies $/ \mathrm{ml}(95 \% \mathrm{Cl}$, 0.97 to $-0.48 ; P<0.0001$ ) in patients who were serum antibody-negative at baseline, while it was $-0.36 \log _{10}$ copies $/ \mathrm{ml}(95 \% \mathrm{Cl},-0.56$ to $-0.16 ; \mathrm{P}=0.0003)$ in the overall mFAS (Table 2; Figure S6). Treatment effects were similar with the low-dose and highdose antibody cocktail across all virologic efficacy endpoint comparisons (Table 2; Figure S6). Results from additional key virologic endpoints are provided in Table S3, Figure S7, and Figure S8.

\section{CLINICAL EFFICACY}

There were two clinical efficacy endpoints prespecified for hierarchical testing: the proportion of patients with at least one Covid-19-related MAV and the proportion of patients with at least one Covid-19-related MAV consisting of only hospitalization or ER or urgent care visits (Table S1; Table 2). Both endpoints were assessed through day 29 in the pooled 799-patient group (group-1+2) who were confirmed SARS-CoV-2-positive by NP RT-qPCR at baseline (mFAS; $n=665$ ). Overall, $67 \%$ of the Covid-19-related 
medRxiv preprint doi: https://doi.org/10.1101/2021.06.09.21257915; this version posted June 12, 2021. The copyright holder for this preprint (which was not certified by peer review) is the author/funder, who has granted medRxiv a license to display the preprint in perpetuity. It is made available under a CC-BY-NC-ND 4.0 International license .

MAVs were hospitalizations or ER visits (30\% and 37\%,respectively), $26 \%$ physician office/telemedicine visits, and 7\% urgent care visits. Descriptions of Covid-19-related MAVs are included in Table S4.

The proportion of patients in the REGEN-COV treatment group (combined 2400mg and $8000 \mathrm{mg}$ dose groups) with $\geq 1$ Covid-19-related MAV was 2.8\% (12 of 434) compared to $6.5 \%$ (15 of 231 ) in the placebo group, which represents a relative reduction of $57 \%$ (absolute difference vs. placebo, -3.7 percentage points; $95 \% \mathrm{Cl},-8 \%$ to $0 \% ; \mathrm{P}=0.0240$ ) (Table 2). Treatment effects observed with REGEN-COV were more pronounced in baseline serum antibody-negative patients (3.4\% versus $9.7 \%$ placebo; $65 \%$ relative reduction) (Table S5). For the final hierarchical endpoint, the proportion of patients with Covid-19-related hospitalization or ER or urgent care visits was numerically lower in the REGEN-COV combined dose group (vs placebo) but the difference did not reach statistical significance (Table 2). Post-hoc analyses demonstrated a reduction in the proportion of antibody cocktail-treated patients (combined dose group) who were hospitalized or died $(0.7 \%$ [3 of 434 ] versus $2.2 \%$ [5 of 231 ] placebo; relative reduction of $68 \%$ ) and in those who were hospitalized or had an ER visit (1.8\% [8 of 434] versus $4.3 \%$ [10 of 231] placebo; relative reduction of $57 \%$ ) (Table S6).

Additional post hoc analyses investigated the effects of the antibody cocktail treatment on MAVs in various high-risk subgroups. The proportion of patients with $\geq 1$ risk factor for hospitalization $(n=408)$ who had $\geq 1$ Covid-19-related MAV in the REGEN-COV group (combined dose group) versus the placebo group was: $2.6 \%$ versus $9.2 \%$ (absolute 
medRxiv preprint doi: https://doi.org/10.1101/2021.06.09.21257915; this version posted June 12, 2021. The copyright holder for this preprint (which was not certified by peer review) is the author/funder, who has granted medRxiv a license to display the preprint in perpetuity. It is made available under a CC-BY-NC-ND 4.0 International license .

difference vs. placebo, -6.5 percentage points; $95 \% \mathrm{Cl},-13$ to $-2 ; 71 \%$ relative reduction) (Figure 2; Table S7). The proportion of patients with $\geq 1$ risk factor who were baseline serum antibody-negative and had a viral load $>10^{4}$ copies $/ \mathrm{ml}(\mathrm{n}=217)$ who had $\geq 1$ Covid-19-related MAV in the REGEN-COV group (combined dose group) versus the placebo group was: $2.1 \%$ versus $13.2 \%$ (absolute difference vs. placebo, -11.0 percentage points; $95 \% \mathrm{Cl},-21$ to $-3 ; 84 \%$ relative reduction) (Table S8). The majority (59\%) of patients who experienced a MAV had a viral load of $\geq 4 \log _{10}$ copies $/ \mathrm{ml}$ around the time of the MAV (Table S4; Figure S9). As with the virologic endpoints, no meaningful differences in clinical outcomes were observed between low-dose and highdose treatments.

\section{SAFETY}

SAEs were experienced by 4 of 258 patients (1.6\%) in the REGEN-COV $2400 \mathrm{mg}$ group, 2 of 260 patients $(0.8 \%)$ in the REGEN-COV $8000 \mathrm{mg}$ group, and a higher number of patients (ie, 6 of 262 patients [2.3\%]) in the placebo group (Table 3; Table S9). All SAEs were considered to be due to advanced or progressive Covid-19 disease and/or associated concomitant clinical conditions and were not evaluated to be related to the study drug treatment.

AESIs - grade $\geq 2$ infusion-related reactions and hypersensitivity reactions - that occurred or worsened during the safety observation period were reported in no patients in the $2400 \mathrm{mg}$ group, $4(1.5 \%)$ patients in the $8000 \mathrm{mg}$ group, and $2(0.8 \%)$ patients in the placebo group (Table 3; Table S9). 
medRxiv preprint doi: https://doi.org/10.1101/2021.06.09.21257915; this version posted June 12, 2021. The copyright holder for this preprint (which was not certified by peer review) is the author/funder, who has granted medRxiv a license to display the preprint in perpetuity.

It is made available under a CC-BY-NC-ND 4.0 International license.

\section{PHARMACOKINETICS}

The mean concentrations for casirivimab and imdevimab increased in a dose-

proportional manner and were consistent with linear pharmacokinetics for single intravenous doses (Table S10). The mean \pm SD day 29 concentrations of casirivimab and imdevimab in serum were $79.7 \pm 34.6$ and $65.2 \pm 28.1 \mathrm{mg} / \mathrm{L}$, respectively, for the low (1200mg) doses and $250 \pm 97.4$ and $205 \pm 82.7 \mathrm{mg} / \mathrm{L}$, respectively, for the high $(4000 \mathrm{mg}$ ) doses (Table S10). 
medRxiv preprint doi: https://doi.org/10.1101/2021.06.09.21257915; this version posted June 12, 2021. The copyright holder for this preprint (which was not certified by peer review) is the author/funder, who has granted medRxiv a license to display the preprint in perpetuity. It is made available under a CC-BY-NC-ND 4.0 International license .

\section{DISCUSSION}

The findings from this final phase $1 / 2$ analysis of REGEN-COV antibody cocktail for the treatment of outpatients with Covid-19 confirm and extend the findings from the first 275 patients. ${ }^{15}$ To better understand the natural history of Covid-19 in outpatients, data from placebo patients in this trial were examined. This data confirms previous findings that patients who at baseline had not yet mounted their own immune response (ie, serum antibody-negative) had median viral loads at baseline that were almost 3 log copies $/ \mathrm{ml}$ higher compared to patients who were serum antibody-positive, and took longer to reach low or undetectable levels. ${ }^{15-17}$ Similar to other viral infections, such as HIV, ${ }^{18}$ ebola virus, ${ }^{19}$ and influenza, ${ }^{20}$ high viral load appears to be a predictor of disease progression in Covid-19, as evidenced by the fact that Covid-19-related MAVs were more frequent in placebo patients with baseline viral loads $>10^{4}$ copies $/ \mathrm{ml}$. The data also indicate that risk factors for severe disease, such as older age and obesity, may help to predict outpatients who are most likely to have a subsequent Covid-19-related MAV. For example, 9.2\% (13/142) of placebo patients with $\geq 1$ risk factor had a MAV compared to $2.2 \%(2 / 89)$ of placebo patients without any risk factors. In this trial, $>80 \%$ of patients with risk factors were serum antibody-negative or had a viral load $>10^{4}$ copies $/ \mathrm{ml}$. In the absence of a rapid serology test or quantitative PCR assay to identify at-risk patients, those with risk factors for hospitalization would be most likely to benefit from early treatment with the antibody cocktail.

The prespecified hierarchical analysis described herein prospectively and with high statistical significance replicates and confirms the virologic efficacy of REGEN-COV as previously reported in an earlier descriptive analysis, and reveals similar virologic 
medRxiv preprint doi: https://doi.org/10.1101/2021.06.09.21257915; this version posted June 12, 2021. The copyright holder for this preprint (which was not certified by peer review) is the author/funder, who has granted medRxiv a license to display the preprint in perpetuity. It is made available under a CC-BY-NC-ND 4.0 International license .

efficacy with both the $2400 \mathrm{mg}$ and $8000 \mathrm{mg}$ doses of the antibody cocktail. ${ }^{15}$ The reduction in viral load was greatest in the first 5 days after treatment, in patients who were serum antibody-negative or who had high viral load at baseline.

The reduction in viral load after treatment with either dose of REGEN-COV was accompanied by a significant reduction in the proportion of patients requiring a subsequent Covid-19-related MAV, the majority (67\%) of which were hospitalizations or ER visits. REGEN-COV antibody cocktail treatment led to a $57 \%$ relative reduction in MAVs (6.5\% placebo versus $2.8 \%$ combined dose group; $P=0.0240)$. Interestingly, the reduction in the proportion of patients with MAVs treated with REGEN-COV compared to placebo occurred only after the first week of treatment. One possible explanation for this finding is that MAVs occurring in the first week are not modifiable despite accelerated clearance of the virus. Indeed, among patients treated with the antibody cocktail, all 3 hospitalizations occurred in the first 3 days after treatment when viral loads were still $\geq 4 \log _{10}$ copies $/ \mathrm{ml}$ but no hospitalizations occurred after day 7 (Table S4; Figure S9). In contrast, among patients treated with placebo, 3 of the 5 hospitalizations occurred after day 7 , when viral loads continued to be high ( $\geq 4 \log _{10}$ copies $/ \mathrm{ml}$ ). These data support early identification and rapid treatment of outpatients with Covid-19 in order to optimize the efficacy of REGEN-COV treatment.

The safety of REGEN-COV antibody cocktail was as previously reported. ${ }^{15} \mathrm{~A}$ low incidence of SAEs, infusion-related reactions, and hypersensitivity reactions was observed. Similar to results reported previously, ${ }^{15}$ concentrations of each antibody in 
medRxiv preprint doi: https://doi.org/10.1101/2021.06.09.21257915; this version posted June 12, 2021. The copyright holder for this preprint (which was not certified by peer review) is the author/funder, who has granted medRxiv a license to display the preprint in perpetuity.

It is made available under a CC-BY-NC-ND 4.0 International license.

serum at day 29 were well above the predicted neutralization target concentration based on in vitro and preclinical data.

REGEN-COV antibody cocktail at the 2400mg dose received Emergency Use Authorization (EUA) from the US FDA in November 2020 for the treatment of mild-tomoderate COVID-19. ${ }^{21}$ The clinical evidence from this trial suggests that treatment has the greatest benefit when given to high-risk patients who present early after diagnosis when they are most likely to have high viral load. There were no adverse findings observed in patients who were serum antibody-positive at baseline. In this pandemic, early treatment of Covid-19 outpatients is crucial and, if unable to rapidly determine viral load or serum antibody status, the risk-benefit assessment supports treatment to prevent MAVs in high-risk patients. 


\section{DATA SHARING}

A data sharing statement provided by the authors is available with the full text of this article.

\section{SUPPORTED BY}

Supported by Regeneron Pharmaceuticals, Inc. Certain aspects of this project have been funded in whole or in part with federal funds from the Department of Health and Human Services; Office of the Assistant Secretary for Preparedness and Response; Biomedical Advanced Research and Development Authority, under OT number: HHSO100201700020C.

\section{FINANCIAL DISCLOSURE}

Disclosure forms provided by the authors are available with the full text of this article.

\section{ACKNOWLEDGEMENT}

We thank the study participants; their families; the investigational site members involved in this trial (principal and subprincipal investigators, listed in the Supplementary Appendix); the Regeneron trial team (members listed in the Supplementary Appendix); the members of the independent data and safety monitoring committee; Brian Head, Ph.D., Caryn Trbovic, Ph.D., and S. Balachandra Dass, Ph.D., from Regeneron Pharmaceuticals for assistance with development of an earlier version of the 
medRxiv preprint doi: https://doi.org/10.1101/2021.06.09.21257915; this version posted June 12, 2021. The copyright holder for this preprint (which was not certified by peer review) is the author/funder, who has granted medRxiv a license to display the preprint in perpetuity. It is made available under a CC-BY-NC-ND 4.0 International license.

manuscript; and Prime for formatting and copy editing suggestions for an earlier version of the manuscript. 
medRxiv preprint doi: https://doi.org/10.1101/2021.06.09.21257915; this version posted June 12, 2021. The copyright holder for this preprint (which was not certified by peer review) is the author/funder, who has granted medRxiv a license to display the preprint in perpetuity. It is made available under a CC-BY-NC-ND 4.0 International license .

\section{REFERENCES}

1. WHO. WHO Director-General's Opening Remarks at the Media Briefing on COVID-19 - 11 March 2020. 2020.

2. Zhu N, Zhang D, Wang W, et al. A Novel Coronavirus from Patients with Pneumonia in China, 2019. N Engl J Med 2020;382:727-33.

3. Goyal P, Choi JJ, Pinheiro LC, et al. Clinical Characteristics of Covid-19 in New York City. N Engl J Med 2020;382:2372-4.

4. Guan WJ, Ni ZY, Hu Y, et al. Clinical Characteristics of Coronavirus Disease 2019 in China. N Engl J Med 2020;382:1708-20.

5. Lapostolle F, Schneider E, Vianu I, et al. Clinical features of 1487 COVID-19 patients with outpatient management in the Greater Paris: the COVID-call study. Intern Emerg Med 2020;15:813-7.

6. Li LQ, Huang T, Wang YQ, et al. COVID-19 patients' clinical characteristics, discharge rate, and fatality rate of meta-analysis. J Med Virol 2020;92:577-83.

7. Richardson S, Hirsch JS, Narasimhan M, et al. Presenting Characteristics, Comorbidities, and Outcomes Among 5700 Patients Hospitalized With COVID-19 in the New York City Area. JAMA 2020;323:2052-9.

8. Fajnzylber J, Regan J, Coxen K, et al. SARS-CoV-2 viral load is associated with increased disease severity and mortality. Nat Commun 2020;11:5493.

9. Magleby R, Westblade LF, Trzebucki A, et al. Impact of SARS-CoV-2 Viral Load on Risk of Intubation and Mortality Among Hospitalized Patients with Coronavirus Disease 2019. Clin Infect Dis 2020.

10. Hansen J, Baum A, Pascal KE, et al. Studies in humanized mice and convalescent humans yield a SARS-CoV-2 antibody cocktail. Science (New York, NY) 2020;369:1010-4.

11. Simoes EAF, Forleo-Neto E, Geba GP, et al. Suptavumab for the Prevention of Medically Attended Respiratory Syncytial Virus Infection in Preterm Infants. Clin Infect Dis 2020.

12. Baum A, Fulton BO, Wloga E, et al. Antibody cocktail to SARS-CoV-2 spike protein prevents rapid mutational escape seen with individual antibodies. Science (New York, NY) 2020;369:1014-8. 
medRxiv preprint doi: https://doi.org/10.1101/2021.06.09.21257915; this version posted June 12, 2021. The copyright holder for this preprint (which was not certified by peer review) is the author/funder, who has granted medRxiv a license to display the preprint in perpetuity. It is made available under a CC-BY-NC-ND 4.0 International license .

13. Wang P, Liu L, Iketani S, et al. Increased Resistance of SARS-CoV-2 Variants B.1.351 and B.1.1.7 to Antibody Neutralization. bioRxiv : the preprint server for biology 2021.

14. Baum A, Ajithdoss D, Copin R, et al. REGN-COV2 antibodies prevent and treat SARS-CoV-2 infection in rhesus macaques and hamsters. Science (New York, NY) 2020;370:1110-5.

15. Weinreich DM, Sivapalasingam S, Norton T, et al. REGN-COV2, a Neutralizing Antibody Cocktail, in Outpatients with Covid-19. N Engl J Med 2020.

16. Wellinghausen N, Plonne D, Voss M, Ivanova R, Frodl R, Deininger S. SARSCoV-2-lgG response is different in COVID-19 outpatients and asymptomatic contact persons. J Clin Virol 2020;130:104542.

17. Wolfel R, Corman VM, Guggemos W, et al. Virological assessment of hospitalized patients with COVID-2019. Nature 2020;581:465-9.

18. Mellors JW, Rinaldo CR, Jr., Gupta P, White RM, Todd JA, Kingsley LA. Prognosis in HIV-1 infection predicted by the quantity of virus in plasma. Science (New York, NY) 1996;272:1167-70.

19. Towner JS, Rollin PE, Bausch DG, et al. Rapid diagnosis of Ebola hemorrhagic fever by reverse transcription-PCR in an outbreak setting and assessment of patient viral load as a predictor of outcome. J Virol 2004;78:4330-41.

20. Li CC, Wang L, Eng HL, et al. Correlation of pandemic (H1N1) 2009 viral load with disease severity and prolonged viral shedding in children. Emerg Infect Dis 2010;16:1265-72.

21. FDA. Casirivimab and imdevimab EUA Letter of Authorization - November 21, 2020. 2020. 


\section{TABLES}

Table 1. Demographic and Baseline Medical Characteristics* (N=799; Full Analysis Set)

\begin{tabular}{|c|c|c|c|c|c|}
\hline Characteristic & $\begin{array}{c}\text { Total } \\
(\mathrm{N}=799)\end{array}$ & $\begin{array}{l}\text { Placebo } \\
(\mathrm{N}=266)\end{array}$ & $\begin{array}{l}\text { REGEN-COV } 2400 \mathrm{mg} \\
(\mathrm{N}=266)\end{array}$ & $\begin{array}{l}\text { REGEN-COV } 8000 \mathrm{mg} \\
(\mathrm{N}=267)\end{array}$ & $\begin{array}{l}\text { REGEN-COV combined } \\
(\mathrm{N}=533)\end{array}$ \\
\hline $\begin{array}{l}\text { Median age } \\
(\text { IQR) - yr }\end{array}$ & $42.0(31.0-52.0)$ & $42.0(32.0-53.0)$ & $42.0(31.0-52.0)$ & $42.0(30.0-52.0)$ & $42.0(30.0-52.0)$ \\
\hline $\begin{array}{l}\text { Male sex - no. } \\
(\%)\end{array}$ & $376(47.1)$ & $134(50.4)$ & $122(45.9)$ & $120(44.9)$ & $242(45.4)$ \\
\hline \multicolumn{6}{|l|}{ Race - no. (\%)† } \\
\hline White & $681(85.2)$ & $227(85.3)$ & $224(84.2)$ & $230(86.1)$ & $454(85.2)$ \\
\hline $\begin{array}{l}\text { Black or African } \\
\text { American }\end{array}$ & $74(9.3)$ & $24(9.0)$ & $27(10.2)$ & $23(8.6)$ & $50(9.4)$ \\
\hline $\begin{array}{l}\text { American } \\
\text { Indian or Alaska } \\
\text { Native }\end{array}$ & $5(0.6)$ & $3(1.1)$ & $1(0.4)$ & $1(0.4)$ & $2(0.4)$ \\
\hline Unknown & $7(0.9)$ & $3(1.1)$ & $1(0.4)$ & $3(1.1)$ & $4(0.8)$ \\
\hline Not reported & $18(2.3)$ & $5(1.9)$ & $7(2.6)$ & $6(2.2)$ & $13(2.4)$ \\
\hline $\begin{array}{l}\text { Median weight } \\
(I Q R)-\mathrm{kg}\end{array}$ & $\begin{array}{c}81.60 \\
(69.90-95.30)\end{array}$ & $\begin{array}{c}81.80 \\
(70.80-94.30)\end{array}$ & $\begin{array}{c}81.60 \\
(69.90-94.50)\end{array}$ & $\begin{array}{c}81.20 \\
(68.00-97.10)\end{array}$ & $\begin{array}{c}81.60 \\
(69.30-95.30)\end{array}$ \\
\hline
\end{tabular}




\begin{tabular}{|c|c|c|c|c|c|}
\hline $\begin{array}{l}\text { Body-mass } \\
\text { index } \neq\end{array}$ & $29.67 \pm 8.228$ & $29.96 \pm 10.460$ & $29.51 \pm 6.413$ & $29.57 \pm 7.355$ & $29.54 \pm 6.890$ \\
\hline $\begin{array}{l}\text { Obesity — no. } \\
(\%) \S\end{array}$ & $298(37.3)$ & $93(35.0)$ & $101(38.0)$ & $104(39.0)$ & $205(38.5)$ \\
\hline \multicolumn{6}{|c|}{ Baseline viral load in nasopharyngeal swab (raw values) } \\
\hline No. of patients & 752 & 259 & 243 & 250 & 493 \\
\hline $\begin{array}{l}\text { Median viral } \\
\text { load (range) - } \\
\text { copies } / \mathrm{ml}\end{array}$ & $\begin{array}{c}304500.0 \\
(1-71000000)\end{array}$ & $\begin{array}{c}437000.0 \\
(1-71000000)\end{array}$ & $\begin{array}{c}295000.0 \\
(1-71000000)\end{array}$ & $\begin{array}{c}262500.0 \\
(1-71000000)\end{array}$ & $\begin{array}{c}270000.0 \\
(1-71000000)\end{array}$ \\
\hline \multicolumn{6}{|c|}{ Baseline viral load in nasopharyngeal swab ( $\log _{10}$ scale) } \\
\hline $\begin{array}{l}\text { Median viral } \\
\text { load (range) }- \\
\log _{10} \text { copies } / \mathrm{ml}\end{array}$ & $5.48(0.0-7.9)$ & $5.64(0.0-7.9)$ & $5.47(0.0-7.9)$ & $5.42(0.0-7.9)$ & $5.43(0.0-7.9)$ \\
\hline \multicolumn{6}{|c|}{ Baseline viral load in nasopharyngeal swab category - no. (\%) } \\
\hline$>10^{4}$ & $523(65.5)$ & $176(66.2)$ & $180(67.7)$ & $167(62.5)$ & $347(65.1)$ \\
\hline$>10^{5}$ & $439(54.9)$ & $149(56.0)$ & $148(55.6)$ & $142(53.2)$ & $290(54.4)$ \\
\hline$>10^{6}$ & $332(41.6)$ & $114(42.9)$ & $110(41.4)$ & $108(40.4)$ & $218(40.9)$ \\
\hline
\end{tabular}




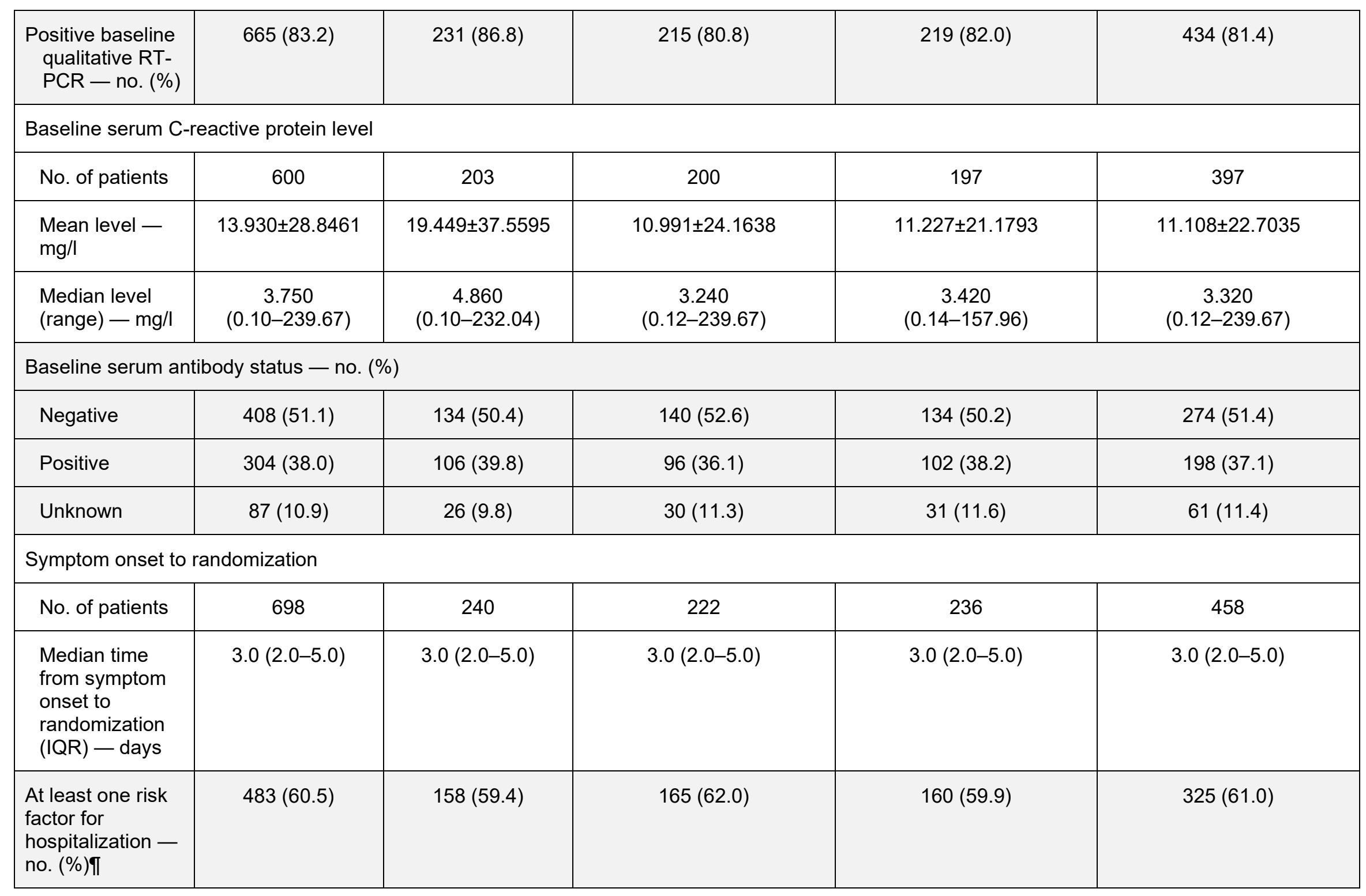


* Plus-minus values are means \pm SD. Percentages may not total 100 because of rounding. IQR denotes interquartile range, RT-PCR reversetranscriptase polymerase chain reaction, and SD standard deviation.

$\dagger$ Race and ethnic group were reported by the patients.

¥ The body-mass index is the weight in kilograms divided by the square of the height in meters.

$\S$ Obesity is defined as a body-mass index of greater than 30 .

Tा Risk factors for hospitalization include an age of more than 50 years, obesity, cardiovascular disease (including hypertension), chronic lung disease (including asthma), chronic metabolic disease (including diabetes), chronic kidney disease (including receipt of dialysis), chronic liver disease, and immunocompromised (immunosuppression or receipt of immunosuppressants). 
Table 2. Key Virologic and Clinical End Points

\begin{tabular}{|c|c|c|c|c|}
\hline End Point & Placebo & REGEN-COV $2400 \mathrm{mg}$ & REGEN-COV $8000 \mathrm{mg}$ & REGEN-COV combined \\
\hline \multicolumn{5}{|c|}{ Time-weighted average change from baseline in viral load* $\left(\log _{10}\right.$ copies $\left./ \mathrm{ml}\right)$ from day 1 through day 7 (analysis group 2) } \\
\hline \multicolumn{5}{|l|}{$\begin{array}{l}\text { Baseline viral load }>10^{7} \\
\text { copies } / \mathrm{ml} \text { (mFAS) }\end{array}$} \\
\hline No. of patients & 70 & 58 & 52 & 110 \\
\hline $\begin{array}{l}\text { Least-squares mean } \\
\text { change (SE) - } \log _{10} \\
\text { copies/ml }\end{array}$ & $-1.46(0.15)$ & $-2.14(0.16)$ & $-2.13(0.16)$ & $-2.13(0.13)$ \\
\hline \multicolumn{5}{|c|}{ Difference vs. placebo at day $7-\log _{10}$ copies $/ \mathrm{ml}$} \\
\hline $\begin{array}{l}\text { Least-squares mean } \\
\text { (SE) }\end{array}$ & & $-0.68(0.16)$ & $-0.68(0.16)$ & $-0.68(0.14)$ \\
\hline 95\% Cl† ( $\mathrm{P}$ value) & & $-0.99,-0.37(<0.0001)$ & $-0.99,-0.36(<0.0001)$ & $-0.94,-0.41(<0.0001)$ \\
\hline $95 \% \mathrm{Cl}$ & $-1.65,-1.14$ & $-2.38,-1.88$ & $-2.24,-1.72$ & $-2.27,-1.85$ \\
\hline \multicolumn{5}{|c|}{ Difference vs. placebo at day $7-\log _{10}$ copies $/ \mathrm{ml}$} \\
\hline $\begin{array}{l}\text { Least-squares mean } \\
\text { (SE) }\end{array}$ & & $-0.73(0.14)$ & $-0.58(0.14)$ & $-0.65(0.12)$ \\
\hline 95\% Cl† (P value) & & $-1.01,-0.45(<0.0001)$ & $-0.86,-0.30(<0.0001)$ & $-0.89,-0.41(<0.0001)$ \\
\hline \multicolumn{5}{|l|}{$\begin{array}{l}\text { Baseline serum antibody } \\
\text { status: negative (mFAS) }\end{array}$} \\
\hline No. of patients & 93 & 80 & 77 & 157 \\
\hline
\end{tabular}




\begin{tabular}{|c|c|c|c|c|}
\hline $\begin{array}{l}\text { Least-squares mean } \\
\text { change (SE) - } \log _{10} \\
\text { copies } / \mathrm{ml}\end{array}$ & $-1.18(0.10)$ & $-1.92(0.11)$ & $-1.90(0.11)$ & $-1.91(0.08)$ \\
\hline $95 \% \mathrm{Cl}$ & $-1.38,-0.99$ & $-2.13,-1.71$ & $-2.11,-1.69$ & $-2.06,-1.76$ \\
\hline \multicolumn{5}{|c|}{ Difference vs. placebo at day $7-\log _{10}$ copies $/ \mathrm{ml}$} \\
\hline $\begin{array}{l}\text { Least-squares mean } \\
\text { (SE) }\end{array}$ & & $-0.74(0.14)$ & $-0.71(0.14)$ & $-0.73(0.12)$ \\
\hline $95 \% \mathrm{Cl}+(\mathrm{P}$ value $)$ & & $-1.02,-0.45(<0.0001)$ & $-1.00,-0.43(<0.0001)$ & $-0.97,-0.48(<0.0001)$ \\
\hline \multicolumn{5}{|l|}{ mFAS } \\
\hline No. of patients & 146 & 137 & 141 & 278 \\
\hline $\begin{array}{l}\text { Least-squares mean } \\
\text { change }(\mathrm{SE})-\log _{10} \\
\text { copies } / \mathrm{ml}\end{array}$ & $-1.30(0.09)$ & $-1.69(0.09)$ & $-1.64(0.09)$ & $-1.66(0.07)$ \\
\hline $95 \% \mathrm{Cl}$ & $-1.49,-1.12$ & $-1.87,-1.50$ & $-1.82,-1.46$ & $-1.81,-1.52$ \\
\hline \multicolumn{5}{|c|}{ Difference vs. placebo at day $7-\log _{10}$ copies $/ \mathrm{ml}$} \\
\hline $\begin{array}{l}\text { Least-squares mean } \\
\text { (SE) }\end{array}$ & & $-0.38(0.12)$ & $-0.34(0.12)$ & $-0.36(0.10)$ \\
\hline 95\% Cl† ( $\mathrm{P}$ value) & & $-0.61,-0.15(0.0011)$ & $-0.57,-0.11(0.0035)$ & $-0.56,-0.16(0.0003)$ \\
\hline \multicolumn{5}{|c|}{ Proportion of patients with Covid-19-related MAVs through day 29 (analysis groups 1+2) } \\
\hline \multicolumn{5}{|l|}{ mFAS } \\
\hline No. of patients & 231 & 215 & 219 & 434 \\
\hline $\begin{array}{l}\text { Patients with } \geq 1 \text { visit within } \\
29 \text { days }- \text { no. }(\%)\end{array}$ & $15(6.5)$ & $6(2.8)$ & $6(2.7)$ & $12(2.8)$ \\
\hline $\begin{array}{l}\text { Difference vs. placebo } \\
\text { — percentage points }\end{array}$ & & -3.7 & -3.8 & -3.7 \\
\hline $95 \% \mathrm{Cl}+(\mathrm{P}$ value $)$ & & $-8.0,0.3(0.0754)$ & $-8.1,0.2(0.0737)$ & $-7.9,-0.3(0.0240)$ \\
\hline \multicolumn{5}{|c|}{$\begin{array}{l}\text { Proportion of patients with subset of Covid-19-related MAVs consisting only of hospitalization or ER visit or urgent care visit through day } 29 \\
\text { (analysis groups } 1+2 \text { ) }\end{array}$} \\
\hline mFAS & & & & \\
\hline
\end{tabular}




\begin{tabular}{|l|c|c|c|c|}
\hline No. of patients & 231 & 215 & 219 & 434 \\
\hline $\begin{array}{l}\text { Patients with } \geq 1 \text { visit within } \\
29 \text { days - no. (\%) }\end{array}$ & $10(4.3)$ & $5(2.3)$ & $5(2.3)$ & $10(2.3)$ \\
\hline $\begin{array}{c}\text { Difference vs. placebo } \\
\text { - percentage points }\end{array}$ & & -2.0 & -2.0 & -2.0 \\
\hline $95 \%$ Cl† (P value) & & $-11.2,7.3(0.2983)$ & $-11.3,7.2(0.2962)$ & $-10.0,6.0(0.1575)$ \\
\hline
\end{tabular}

* The time-weighted mean change in viral load was based on an analysis of covariance model with treatment group, risk factor, and baseline antibody status as fixed effects and baseline viral load and treatment group-by-baseline viral load as covariates. Confidence intervals were not adjusted for multiplicity.

† Confidence intervals for the difference (REGEN-COV minus placebo) were based on the exact method and were not adjusted for multiplicity. 
Table 3. Overview of Serious Adverse Events and Adverse Events of Special Interest in the Safety Population

\begin{tabular}{|c|c|c|c|c|}
\hline Event & $\begin{array}{l}\text { Placebo } \\
(\mathrm{N}=262)\end{array}$ & $\begin{array}{l}\text { REGEN-COV 2400mg } \\
(\mathrm{N}=258)\end{array}$ & $\begin{array}{l}\text { REGEN-COV } 8000 \mathrm{mg} \\
(\mathrm{N}=260)\end{array}$ & $\begin{array}{l}\text { REGEN-COV combined } \\
(\mathrm{N}=518)\end{array}$ \\
\hline \multicolumn{5}{|c|}{ no. of patients (percent) } \\
\hline Any serious adverse event & $6(2.3)$ & $4(1.6)$ & $2(0.8)$ & $6(1.2)$ \\
\hline $\begin{array}{l}\text { Any adverse event of special } \\
\text { interest* }^{*}\end{array}$ & $2(0.8)$ & 0 & $4(1.5)$ & $4(0.8)$ \\
\hline $\begin{array}{l}\text { Any serious adverse event of } \\
\text { special interest* }^{*}\end{array}$ & 0 & 0 & 0 & 0 \\
\hline $\begin{array}{l}\text { Grade } \geq 2 \text { infusion-related reaction } \\
\text { within } 4 \text { days }\end{array}$ & $1(0.4)$ & 0 & $4(1.5)$ & $4(0.8)$ \\
\hline $\begin{array}{l}\text { Grade } \geq 2 \text { hypersensitivity reaction } \\
\text { within } 29 \text { days }\end{array}$ & $2(0.8)$ & 0 & 0 & 0 \\
\hline \multicolumn{5}{|c|}{ Patients with adverse events that occurred or worsened during the observation period $\dagger$} \\
\hline Patients with grade 3 or 4 event & $4(1.5)$ & $3(1.2)$ & $2(0.8)$ & $5(1.0)$ \\
\hline $\begin{array}{l}\text { Patients with adverse event that } \\
\text { led to death }\end{array}$ & 0 & 0 & 0 & 0 \\
\hline $\begin{array}{l}\text { Patients with adverse event that } \\
\text { led to withdrawal from the trial }\end{array}$ & 0 & 0 & $1(0.4)$ & $1(0.2)$ \\
\hline $\begin{array}{l}\text { Patients with adverse event that } \\
\text { led to infusion interruption* }\end{array}$ & $1(0.4)$ & 0 & $1(0.4)$ & $1(0.2)$ \\
\hline
\end{tabular}

* Events were grade 2 or higher hypersensitivity reactions or infusion-related reactions.

$\dagger$ Events listed here were not present at baseline or were an exacerbation of a preexisting condition that occurred during the observation period, which is defined as the time from administration of REGEN-COV or placebo to the final follow-up visit. 
It is made available under a CC-BY-NC-ND 4.0 International license.

\section{Figure 1. SARS-CoV-2 Viral Load Over Time}

A. Viral Load over Time in the Overall Population

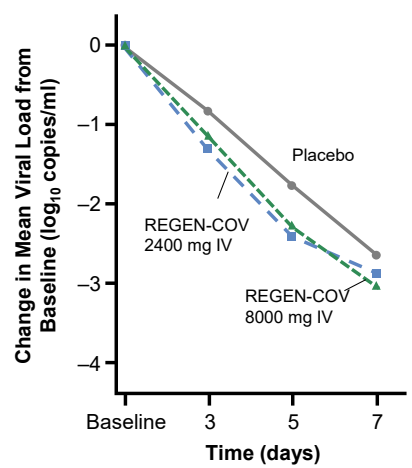

No. at Risk

Placebo

REGEN-COV $2400 \mathrm{mg}$ IV

$\begin{array}{llll}150 & 136 & 143 & 146 \\ 142 & 132 & 137 & 137 \\ 145 & 135 & 140 & 141\end{array}$

B. Viral Load over Time According to Baseline Antibody Status

Serum Antibody-Negative

Serum Antibody-Positive
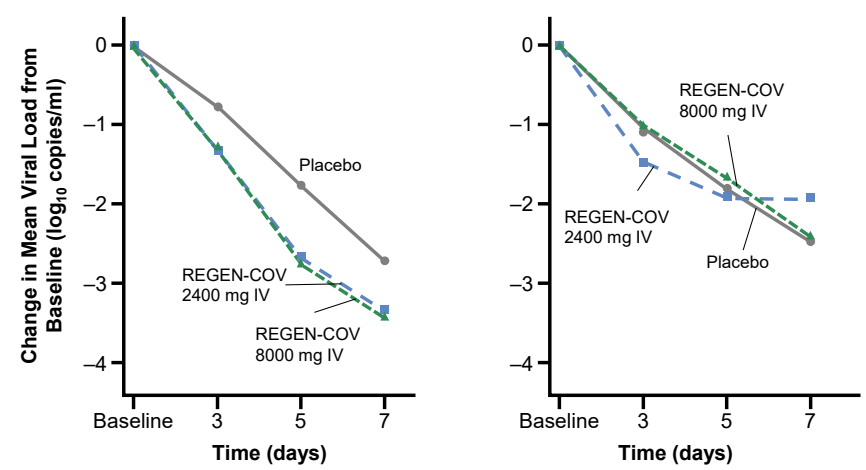

No. at Risk

$\begin{array}{lllll}\text { Placebo } & 94 & 87 & 91 & 93 \\ \text { REGEN-COV } 2400 \mathrm{mg} \mathrm{IV} & 83 & 78 & 80 & 80 \\ \text { REGEN-COV } 8000 \mathrm{mg} \text { IV } & 79 & 73 & 76 & 77\end{array}$

C. Viral Load over Time According to Baseline Viral Load Category

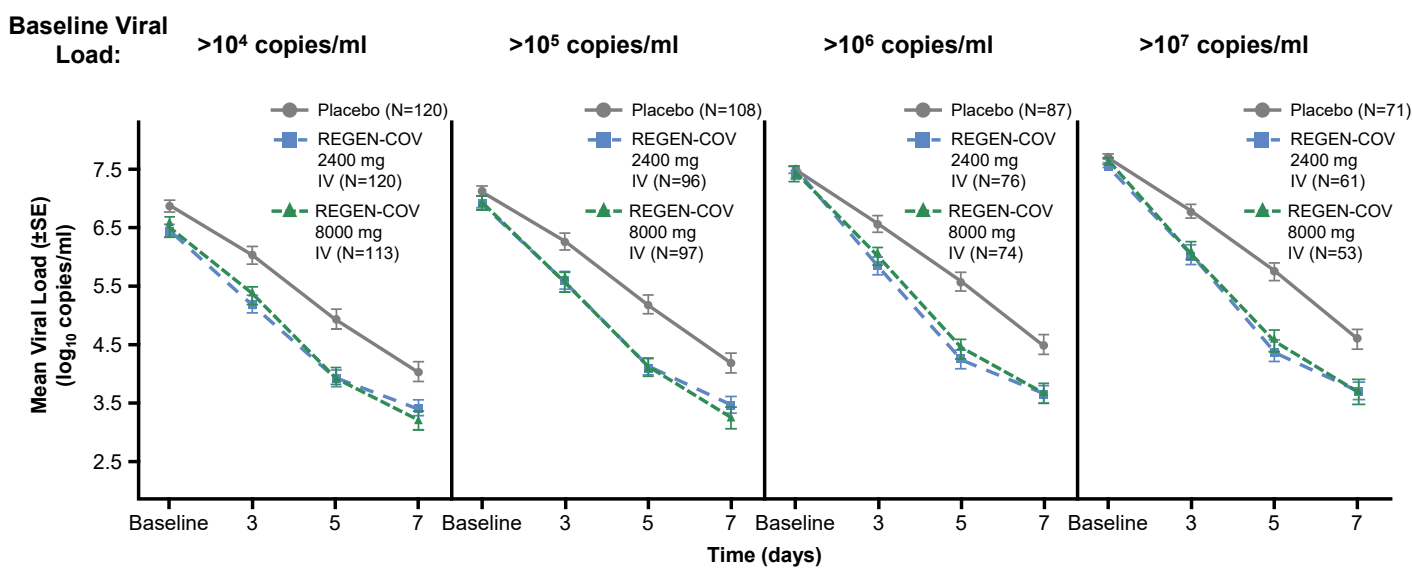

The lower limit of detection (dashed line) is 714 copies per milliliter (2.85 log 10 copies per milliliter) IV, intravenous(ly); SE, standard error. 
Figure 2. Proportion of Patients with Covid-19-related MAVs

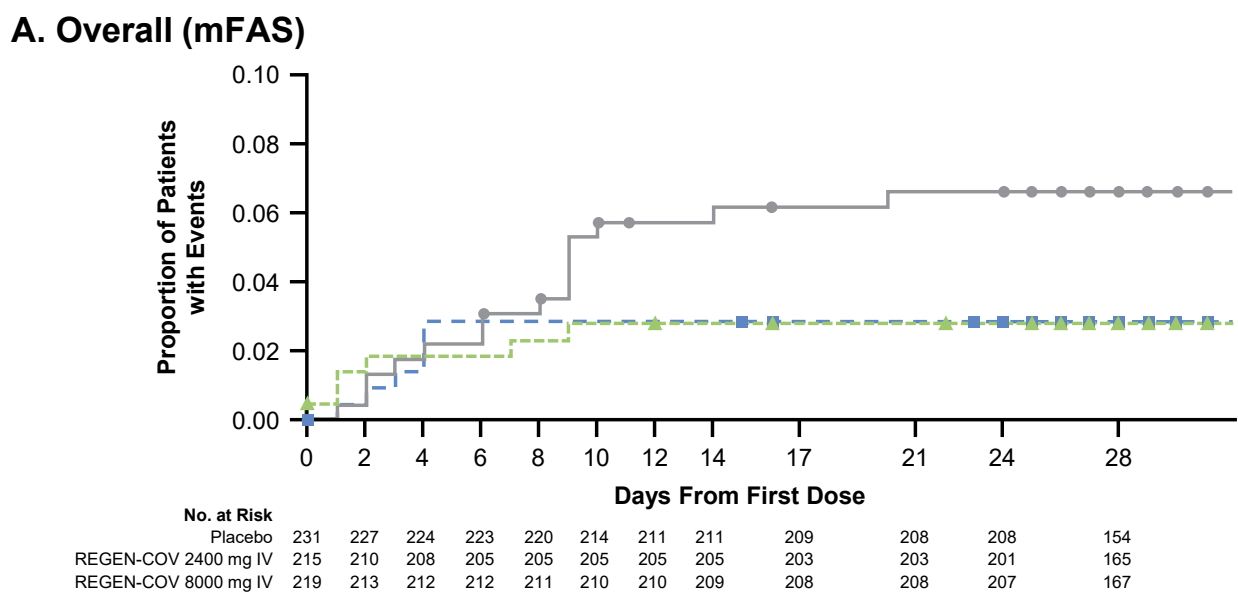

B. No Risk Factor for Hospitalization

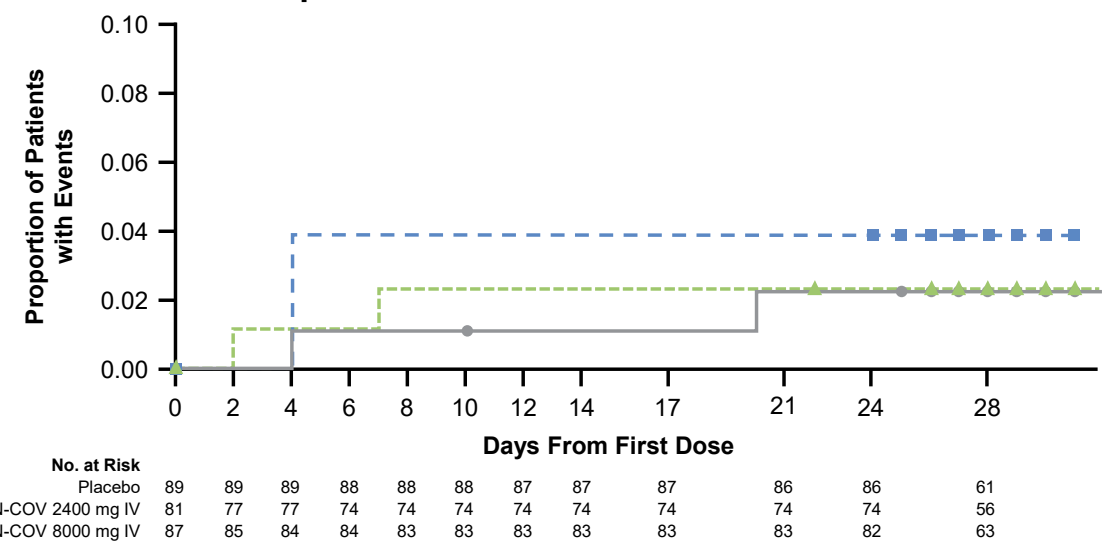

C. $\geq 1$ Risk Factor for Hospitalization

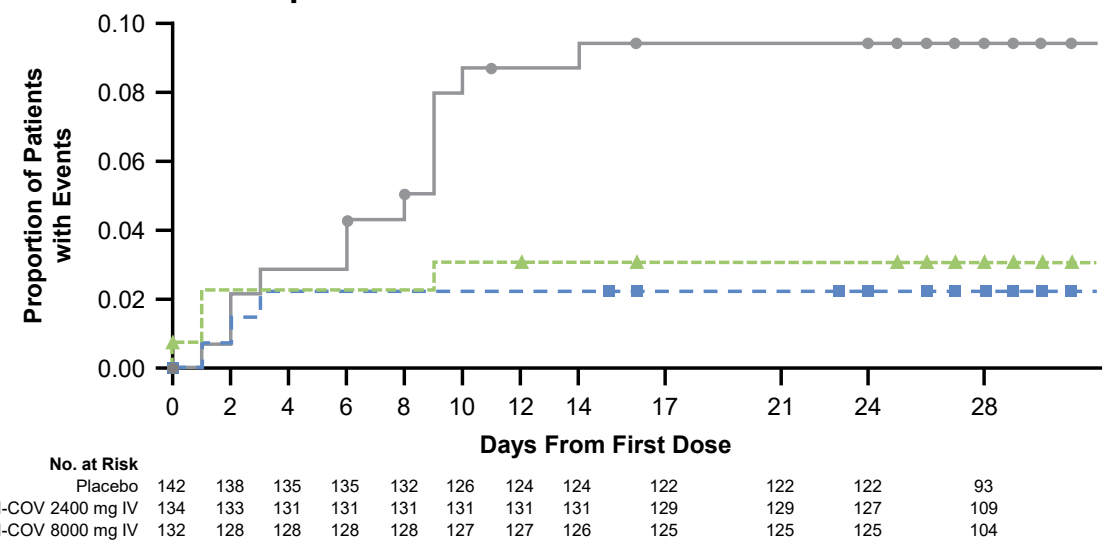

$\because$ Placebo $\quad-$ REGEN-COV $2400 \mathrm{mg}$ IV $\quad=-1$ - REGEN-COV $8000 \mathrm{mg}$ IV 